\title{
AUTONOMOUS LEARNERS: HOW COMPETENCY-BASED CURRICULUM COULD ACCELERATE EFL AT ENGLISH EDUCATION DEPARTMENT
}

\author{
Jati Suryanto \\ Universitas Muhammadiyah Yogyakarta. \\ jatisuryanto@umy.ac.id
}

\begin{abstract}
This paper will explore the implementation of the Competency-Based Curriculum at the Department of English Education, Universitas Muhammadiyah Yogyakarta, in reaching the goal of creating autonomous learners. Autonomous Learner is the ultimate objective in teaching learning processes. It is the beginning of the long-life learning processes. By creating autonomous learners, the process of achieving better graduate quality will be more effective and efficient. To reach the goal of producing autonomous learners, the Department of English Education, Universitas Muhammadiyah Yogyakarta, focuses its curriculum on the graduate abilities in "thinking how to think" and "learning how to learn" through the Competency Based Curriculum.

Competency-Based Curriculum $(C B C)$ is the teaching learning planning which bases its objectives on the students' competences. To achieve the ultimate goal of language learning the Department of English Education, Universitas Muhammadiyah Yogyakarta needs to choose the relatively most effective curriculum and method of teaching for the students. Therefore, the department chooses CBC that applies student centred learning (SCL) to achieve the autonomous learning model. The department also applies constructivism approach which enhance the students curiosity to accelerate the autonomous learning in the student centred learning.
\end{abstract}

Keywords: Autonomous Learner, Competency-Based Curriculum, Student Centred Learning, Constructivism.

\section{Introduction}

Traditional education focuses its activities on teaching and it does not focus on learning. In the class, when a teacher explains, students will learn and will get much information from the activities and they will understand most of what the teachers explain. However, most of what students learn before, during, and after attending schools is learned without being taught to the students. A child learns fundamental things, let say, how to walk, talk, eat, and so on without teachers who taught these things. Adults learn most of the equipment at work in the place where they work. They operate any tools at home without being taught by teachers. Most of what people learn in classroom settings is forgotten, and much of what is remembered is irrelevant.

In most schools, memorization is mistaken for learning. Most of what is remembered is remembered only for a short time, but then is quickly forgotten. Furthermore, most children think that most of what they want to know at school can better be done by doing themselves in computers, recording machines, cameras, and so on. Why doesn't education focus on what humans can do better than the machines and instruments they create?

When those who have taught others are asked who in the classes learned most, most of them say, "The teacher." It is apparent to those who have taught that teaching is a better way to learn than being taught. Teaching enables the teacher to discover what one thinks about the subject being taught. In another word, students will get better understanding when they teach the subject matters to other people. Thus, students should be teaching rather than learning.

In formal education, a curriculum is the planned interaction of pupils with instructional content, materials, resources, and processes for evaluating the attainment of educational objectives. Curriculum can also be defined as all the learning which is planned and guided by the school, whether it is carried on in groups or individually, inside or outside the school. However, curriculum is the total learning experience provided by a school. It 
includes the content of courses (the syllabus), the methods employed (strategies), and other aspects, like norms and values, which relate to the way the school is organized.

Competency Based Curriculum (CBC) is a curriculum that focuses on the students' competency as the ultimate goal of the learning process. A good curriculum is that when it can guide the teachers motivate and inspire the students to get what they want to learn themselves. A good curriculum should drive students do more activities than what the teachers do in the class.

This paper would discuss whether the CBC could accelerate the students learning autonomy in the English Education Department (EED), Universitas Muhammadiyah Yogyakarta (UMY). The department applies the $\mathrm{CBC}$ since the beginning of the department when it was established in May 2010. This paper is the result of the observation of the implementation of the curriculum from 2010 to 2013.

\section{Autonomous Learning}

Autonomous learning or self-directed learning has been variously defined. Autonomy is defined first as the ability to take charge of one's own learning (Holec, 1979). Another scholar define that autonomy is a situation in which the learner is totally responsible for all the decisions concerned with his [or her] learning and the implementation of those decisions (Dickinson, 1987). Another definition of autonomy is that autonomy is recognition of the rights of learners within educational systems (Benson, 1997). Some people also define it as letting students choose their own topics and activities for homework. Others say that a self-directed learner is one who is self-motivated, one who takes the initiative, one who has a clear idea of what he wants to learn, and one who has his own plan for pursuing and achieving his goal. However, from many definitions, we can take some key characteristics of a learner who can take responsibility for learning: an ability to define one's own objectives; awareness of how to use learning materials effectively; careful organization of time for learning, and active development of learning strategies (Hedge, 2000).

One of the key aspects to consider in defining learner autonomy is whether we view it as a means to an end of learning or as an end in itself of making people autonomous learners. These two options do not exclude each other, both of them can be part of our views towards language learning or learning in general. Therefore the principles of learner autonomy could be:

- autonomy means moving the focus from teaching to learning

- autonomy affords maximum possible influence to the learners

- autonomy encourages and needs peer support and cooperation

- autonomy means making use of self/peer assessment

- the role of the teacher as supporting scaffolding and creating room for the development of autonomy is very demanding and very important

- autonomy means empowering students, yet the classroom can be restrictive, but the use of technology can take students outside of the structures of the classroom, and the students can take the outside world into the classroom

Based on the above definition, we could take some key performance indicators of what an autonomous learner should perform. A self -directed learner should:

- know their needs and work productively with the teacher towards the achievement of their objectives;

- learn both in and outside the classroom;

- be able to take classroom-based material and be able to build on it;

- know how to use resources independently;

- learn with active thinking;

- adjust their learning strategies when necessary to improve learning;

- manage and divide the time in learning properly;

- not think the teacher is a god who can give them ability to master the language.

These key performance indicators, then would be used to measure whether or not the application of the competency based curriculum at the Department of English Education, Universitas Muhammadiyah Yogyakarta could empower the student become sefldirected learners.

\section{Competency Based Curriculum}

Competency-based learning or Competency Based Education and Training is an approach to teaching and learning more often used in learning concrete skills than abstract 
learning. It differs from other non-related approaches in that the unit of learning is extremely fine grained. Rather than a course or a module, every individual skills/learning outcome, known as a competency, is one single unit. Learners work on one competency at a time, which is likely a small component of a larger learning goal. The student is evaluated on the individual competency, and only once they have mastered it, they move on to others. After that, higher or more complex competencies are learned to a degree of mastery and isolated from other topics. Another common component of Competency-based learning is the ability to skip learning modules entirely if the learner can demonstrate they already have mastery. That can be done either through prior learning assessment or through formative testing.

Competency-based learning is learner focused and works naturally with independent study and with the instructor in the role of facilitator. Learners often find different individual skills more difficult than others do. This learning method allows a student to learn those individual skills they find challenging at their own pace, practicing and refining as much as they like. Then, they can move rapidly through other skills to which they are more adept.

\section{The process of developing the competency} based curriculum.

The department of English Education, UMY develops its curriculum based on its vision, mission and objectives of the study program and the SWOT analysis. The department vision is "Becoming an International Standard English Education Study Program which is leading through education, research and social service activities based on Islamic values. The department's mission is to hold the three pillars of higher education in the field of English education based on Islamic values by carrying out (1) education and training which embodying students with English educations science and soft skills using Competency-Based Curriculum and (2) research and social services related to the need of Indonesian society. The objective of the department is to produce under graduates scholars who master English Language and Education with Islamic worldviews.
Based on the department's vision, mission and objective, the faculty members discuss the learning outcomes by defining the graduate profiles. They decided that the department would direct the graduates as English teachers, practitioners in language such as translators, interpreters or any related jobs, language and education researchers and businessperson in language or language educations.

From the profile, then they define the competencies that the students should achieve to perform in those occupations. The competencies were developed based on the principles of what they can do (psychomotor), what they should know (cognitive) and what attitude they have to perform (affective). From the above principles, they decide the learning outcomes or they also call as the main competencies. They are: (1) Able to practice English correctly and fluently and teach it according to the principles of language learning and teaching; (2) Mastering the theory of English language and language learning and teaching; (3) Able to make an academic decision on the use of language and language learning and teaching (4) Able to carry out researcher on language and education, and (5) Possessing intra and interpersonal skills.

Beside the main competencies, the department has also decided the supporting competencies such as (1) Mastering and able to apply Information and Communication Technology effectively in mastering the language and language learning and teaching; (2) Mastering and able to apply entrepreneurship effectively; (3) Mastering and able to apply Islamic values in the professional field and in the society; and (4) Mastering and able to apply national values in the professional field and in the society.

Based on the above competencies, the department identifies all the materials for the entire curriculum based on the main subjects, supporting subjects and the subject matters, which the graduates need in their future carrier. There are 40 subjects, which are structured in 8 semesters. The curriculum is structured based on Richards and Rogers (2001) theory with a little bit modifications. The structure is as follows: 
Tabel 1

The Learning Structure

\begin{tabular}{|l|l|l|l|}
\hline YEAR 1 & Skill-based learning & Language Skills & What to teach \\
\hline YEAR 2 & Theoretical-based learning & $\begin{array}{l}\text { Theories of language learn- } \\
\text { ing and teaching }\end{array}$ & How to teach \\
\hline YEAR 3 & Practical-based learning & Practice on how to teach & $\begin{array}{l}\text { How to apply teaching } \\
\text { learning processes }\end{array}$ \\
\hline YEAR 4 & Research-based learning & $\begin{array}{l}\text { Research on language and } \\
\text { education }\end{array}$ & $\begin{array}{l}\text { How to develop lan- } \\
\text { guage and education sci- } \\
\text { ence }\end{array}$ \\
\hline
\end{tabular}

From the above curriculum structure, all the subject matters are arranged to achieve the goal, a competent English teacher with four major competencies such as: professional competency (what to teach and how to know), pedagogical competency (how to teach and how to do), personal competency (how to be) and social competency (how to live together). The department hopes that after following all the subjects, the graduates would be able to be professionals in the language and language learning and teaching, especially English. By mastering the four major teacher's competencies, they would be beneficial not only for the schools, their students, but also for the society and humanity.

Implementation of Competency Based Curriculum at Universitas Muhammadiyah Yogyakarta, Indonesia

The Department of English Education UMY starts developing its curriculum from the vision and mission of the department. The Department's vision is "Becoming the international standard of English Education Department which is leading on its educational activities, researches and social services based on Islamic values." It means, the Department should manage the institution to achieve international standard and should educate the students that when they graduate they could perform Islamic attitude and behaviour. To achieve the goal, the Department of English Education has focused at least on two major strategies namely the teaching methodology and the teaching learning processes.

\section{The teaching methodology}

The Competency Based Curriculum (CBC) applied by the Department of English Education, Universitas Muhammadiyah Yogyakarta (UMY) is a learning process based on the competency. It means that the learning processes should base on the learners. The teaching learning processes would be called successful when all the students are active in all activities held by the department especially in learning teaching processes. To do so, the Department should carefully choose the teaching methodology that supports the strategies in achieving the goals. For this goal, the Department chooses Student Centred Learning as the methodology with some important points such as Creativity Development; Creating Challenging and Enjoying Condition; Providing Various Learning Experience, Learning by Doing; and Contextual Learning.

It is very important that the department use Student Centred Learning because developing students' competencies should only be successful when the students become the object of the learning teaching processes. The teacher should be a facilitator in the class who should foster the students develops their creativity that they always find the best way in learning the subject maters in the class. The teacher should also create challenging and enjoying condition of the class that the students would not get bored in the class.

In student centred learning, the teachers who becomes facilitators should provide the class with various learning experience. Students will optimally improve their knowledge and skills when they get more learning experience. Therefore, the activities in the class should support the students to have various types of learning experience. It is also an affirmative that the faculty members of the EED apply the process of learning by doing. The students should not only learn the subject matters cognitively but also practice what they should do when they are in the field of job. 
Contextual learning is also important to apply in the students centred learning processes. The teachers should develop some important factors in EED when they apply contextual learning. They are inquiry; questioning; constructivism; learning community; modelling; authentic assessment; and reflection.

Inquiry is "a seeking for truth, information, or knowledge -- seeking information by questioning." In applying inquiry activity in the classroom teaching, the students should formulate the problem, collect data through observation, analyze and present data and communicate and present the result of data to the readers, classmates, and the other audients.

Questioning is the mother of contextual teaching and learning, the beginning of knowledge, the heart of knowledge and the important aspect of learning. In the class, the teacher asks the students before, during and after the lesson. In a productive teaching learning, questioning activity are useful for checking students comprehension, solving problem faced by students, stimulating responses to the students, measuring student's curiosity, focusing student attention, and refreshing students prior knowledge.

Constructivism is the foundation of CTL. The basic premise is that an individual learner must actively "build" knowledge and skills. In the teaching learning process, the application of constructivism are applied in five step of learning that are activating knowledge, acquiring knowledge, understanding knowledge, applying knowledge and reflecting on knowledge. The constructivism paradigm has led us to understand how learning can be facilitated through certain types of engaging, constructive activities. This model of learning emphasizes meaning making through active participation in situated context socially, culturally, historically, and politically.

Learning community is useful in the CTL that students can get the result of learning through sharing with friends, or other groups. In another words, learning community can also mean group of learning which communicate to share the idea and experience and work together to solve the problem.

Modelling is verbalization of ideas. The teacher should demonstrate the activities that the students should perform. Students usually learn from the model that the teacher performs in the class. Therefore, the teacher should give examples of what the teacher want the student do in the learning teaching processes.

Authentic assessment is a procedure of achievement in the CTL. Assessments of the students' performance can come from the teacher and the students. Authentic assessment is the process of collecting the data that can give the description of student learning development. In the learning process teacher can provide accurate assessments for the students, however, students can also be an effective monitor and judge for their own learning activities. Authentic assessment has some characteristics such as (a) involves real world experience, (b) allows access to information, (c) encourages the use of any tools such as computer, dictionary and other resources, (d) engages the students by relevance, (e) uses open-ended format, (f) Includes selfassessment and reflection, (g) warrant effort and practice, (h) identifies strength to enable students to show what they can do and (i) make assessment criteria clearer to students. Essentially, the question that needs to answer by authentic assessment is "Does the students learn something?" not "What have they already known?". So, the students are assessed through many ways of assessment.

Reflection is the ways of thinking about what the students have learned and thought about what the students have done in the past. Teacher needs reflections from the students in the end of teaching learning process. The reflection can be direct statement about the lesson, some impression and suggestion from students about the learning process and discussion or other related reflections.

\section{Evaluation model}

The last important factor on the $\mathrm{CBC}$ is the evaluation model. Evaluation is important to measure the success of the learning teaching processes. The EED apply some models of evaluation such as performance assessment; systematic observation; portfolio; and science journal.

The EED applies performance assessment because CBC does not only deal with cognitive and psychomotor domain. It should also develop the affective domain. It is easy to 
measure the cognitive ability of the students as well as the psychomotor skills. Teacher could just give any tests or a certain task to know that the students have achieved a certain level. However, affective skills could not easily be measured using such test or task. Teacher should apply performance assessment to measure the level of the psychomotor and affective skills of the students.

The systematic observation and portfolio are important for the $\mathrm{CBC}$ that base on the process of learning and not just the result of the learning. To measure the students' competencies, the teacher could have a systematic observation and portfolio that could assess the day-to-day development of the students' competencies. Science journal is also used as one of the assessment method because by using it, the teacher could easily measure the level of the cognitive ability of the students

\section{The teaching learning processes}

The EED has also standardized the learning processes. Teachers could explore their individual creativity in the learning process, however, the department has given some basic guidelines that the lectures role is the facilitator in the class. Lecturers may open the class and give a scenario or problem that the students discuss the problem and find the solution. To identify the problem and find the solution, the students do a library research in the libraries, Self Access Centre, American Corners or other possible learning centres in the university. Students, then present the research result in the class. Students could make some group and individual power points presentation to present their research and discussion.

In the learning process, the student can apply the seven jumps process to make the learning process be more effective, especially in identifying the problems and finding the solutions. The seven processes are as follows:

1. Clarifying difficult words or terms of the subject matters;

2. Identifying the problems

3. Brainstorming of the hypothesis or some possible clarification and explanations

4. Drawing hypothesis

5. Deciding the learning objectives

6. Data collecting and independent learning
7. Sharing information and discussing the result of the independent learning

\section{Internship}

To support the theoretical understanding, the students should do an internship on teaching practices. They have to go to elementary schools and observe the students learning styles. They have to handle an English extracurricular programme supervised by the English teacher in the school. While teaching English in the class, the other members of the group observes what happens in the class and take notes on the phenomena appear in the class, especially in the students learning styles. They do this practicum for one-semester period. The class is divided into 5 groups and they teach in class 1 until 5. Periodically, they discuss the problems and every semester they have to report what they have done in the school. The next semester they do similar thing but they have to focus on the classroom management. The result of the first year practicum will be beneficial for their study in the second year. When they learn the principles of learning and teaching and other related subjects in the second year, they have got much experience about the real practice of learning a language, especially English in the real school setting.

In the second year, the students should go to a secondary school to have another internship. In this school, they do another observation with the focus on how the teacher develops the lesson plan and how the teacher develops the material development. The students do not only handle an extracurricular class of English but also observe the lesson plan develop by the teacher. They do it in onesemester period and they have to write a report on it. In the next semester, they observe the teaching materials developed by the teacher and try to apply it in their class under the supervision of the English teacher. In the end of the semester, they have to write an official report for their practicum.

In the third year, the students have to deal with the fifth and sixth internship in a senior high school. Similar with the previous practicum, they have to handle an extracurricular English class focussing an observation on the teaching strategy. In this practicum, 
they do not only do an observation but also practice the theories they have in the third and fourth semesters. After doing it in one semester, they do the last internship focussing in language evaluation. They help the English teacher in the school in evaluating the students' proficiency.

\section{Bridging course for Soft Skills}

Most subjects given in the university tend to deal with cognitive and psychomotor domain. However, the CBC urges the department develop the affective domain in all the subjects given to the students. The EED embedded the soft skills in the learning teaching processes to develop the students' affective domain. To focus on the intrapersonal and interpersonal skills, the Department hold six bridging courses on soft skills once every semester. These bridging courses are aimed to give specific theme in every semester that the faculty members could discuss it in every lesson they give in the class.

The first bridging course is the achievement motivation training. This outbound training is aimed to realize the students that their future job is a teacher who have to be able to motivate the students to achieve their goal in studying. To be a motivator, one should be able to motivate himself first. In this training, they will get the intra and interpersonal skills especially in self-awareness, goal setting, time management and achievement motivation.

The second outbound training is held in the second semester to give a thematic soft skill development of creativity. A teacher should motivate the students so that they think, learn and behave creatively. To give a model to the students, prospective teachers should train themselves to be creative; therefore, the department give creativity training to the students to develop their affective soft skill.

Learning organization and team building are also important for the students. In their future career, a teacher would be working on an organization that it is important that they could be active members as the subsystem of a big system. A teacher could not work alone; they have to be a team of teachers. They have to possess personal and social competencies that they could work collectively. Therefore, team building is something important for them.

In the third year, the students have communication and leadership skills. These two soft skills are very important in their future career. Teachers should produce leaders. Only good leaders could produce good leaders. When the students could communicate well and could perform wonderful leadership skills, they would easily get the best job they want.

These sets of outbound training, in fact, do not only make the students perform better attitude but also make the students have closer relationship among them and between the students and the lecturers. It could happen because these trainings should be handled by all the teachers and non academic staff of the department.

\section{The result of the teaching learning processes}

After running the program for three years, the department could report many advantages from the implementation of the $C B C$. The curriculum that requires the department apply students centred learning has create autonomous learners. Most students show their eagerness in learning and they become active not only in the class but outside the class. They are eager to learn the subject matters creatively as well as active in many extracurricular activities.

The seven jumps processes that the students apply in the learning teaching in the class have force the students active both inside and outside the class. They feel that missing the class would make them find many difficulties in following the class that it makes their class attendance almost perfect. Most students attend the class more than $75 \%$ of the total meetings.

Students are also active in consulting many problems to the lecturers outside the class. They usually consult not only their academic problems but also their personal problems. This happens in result of the contextual learning process in the classroom. They are also active consulting many activities that they 
want to join such as in many academic competition and non-academic competition.

Their eagerness in knowing many things and their autonomous learning attitudes have led them hand many achieve- ments. Below is some of the students' achievement that the department has recorded:

Table 2. List of Students' Achievement

\begin{tabular}{|c|c|c|c|c|}
\hline No & Activities & Time & Level & Achievement \\
\hline 1 & $\begin{array}{l}\text { Mimbar Pertunjukan Sastra Dinas Kebu- } \\
\text { dayaan DIY in RRI Pro } 2 \text { Yogyakarta } \\
\text { (Savanna) }\end{array}$ & $\begin{array}{l}1 \text { September } \\
2017\end{array}$ & Regional & $\begin{array}{l}\text { English Musical } \\
\text { Drama "Roro } \\
\text { Jongrang" }\end{array}$ \\
\hline 2 & $\begin{array}{l}\text { The 14th JETA National Conference di } \\
\text { Universitas Sarjanawiyata Tamansiswa }\end{array}$ & $\begin{array}{l}\text { 22-23 May } \\
2017\end{array}$ & National & $\begin{array}{l}\text { Paper presenters: } \\
5 \text { presenters }\end{array}$ \\
\hline 3 & $\begin{array}{l}\text { International Youth Festival } 2017 \\
\text { (Savanna) }\end{array}$ & 2017 & Local & $\begin{array}{l}\text { English musical } \\
\text { drama } \\
\text { "Sangkuriang" }\end{array}$ \\
\hline 4 & $\begin{array}{l}\text { Student Exchange ke Sias } \\
\text { International University, Tiongkok for } \\
\text { one semester in odd Semester } \\
\text { 2015/2016 }\end{array}$ & 2016-2017 & $\begin{array}{l}\text { Interna- } \\
\text { tional }\end{array}$ & $\begin{array}{l}\text { Awardees: } 2 \text { stu- } \\
\text { dents }\end{array}$ \\
\hline 5 & $\begin{array}{l}\text { SEAKATEN International Culture Festi- } \\
\text { val, } 2016 \text { (Savanna) }\end{array}$ & 2016 & Local & $\begin{array}{l}\text { English Musical } \\
\text { Drama “Ken } \\
\text { Arok Ken Dedes" }\end{array}$ \\
\hline 6 & $\begin{array}{l}\text { Conference “Language: Promoting } \\
\text { Value Education" }\end{array}$ & 30 June 2016 & National & $\begin{array}{l}\text { Paper presenters: } \\
5 \text { presenters }\end{array}$ \\
\hline 7 & $\begin{array}{l}\text { Student Exchange ke Sias } \\
\text { International University, Tiongkok } \\
\text { for one semester in odd Semester } \\
2015 / 2016\end{array}$ & 2015-2016 & $\begin{array}{l}\text { Interna- } \\
\text { tional }\end{array}$ & $\begin{array}{l}\text { Awardee: } 1 \text { per- } \\
\text { son }\end{array}$ \\
\hline 8 & $\begin{array}{l}\text { PTNNT scholarship- batch IX, } \\
\text { 2015/2016 PT Newmont Nusa Tenggara }\end{array}$ & $2015-2016$ & National & $\begin{array}{l}\text { Scholarship } \\
\text { holder: } 1 \text { person }\end{array}$ \\
\hline 9 & $\begin{array}{l}\text { International students exchange program } \\
\text { to Spain (Unersitate Jaume I, Castellon } \\
\text { de La Plana) }\end{array}$ & 2016 & $\begin{array}{l}\text { Interna- } \\
\text { tional }\end{array}$ & $\begin{array}{l}\text { Awardee: } 1 \text { per- } \\
\text { son }\end{array}$ \\
\hline 10 & $\begin{array}{l}\text { The 4th Graduate Students } \\
\text { Conference on English Education, } \\
\text { Linguistics, and Literature at USD }\end{array}$ & $\begin{array}{l}28 \text { November } \\
2015\end{array}$ & National & $\begin{array}{l}\text { Paper presenters: } \\
1 \text { Presenter }\end{array}$ \\
\hline 11 & $\begin{array}{l}\text { International students exchange program } \\
\text { to Spain (Unersitate Jaume I, Castellon } \\
\text { de La Plana) }\end{array}$ & $\begin{array}{l}\text { February- July } \\
2015\end{array}$ & $\begin{array}{l}\text { Interna- } \\
\text { tional }\end{array}$ & $\begin{array}{l}\text { Awardees: } 3 \text { per- } \\
\text { sons }\end{array}$ \\
\hline
\end{tabular}


Autonomous Learners...(Suryanto)

\begin{tabular}{|c|c|c|c|c|}
\hline 12 & $\begin{array}{l}\text { Outstanding students scholarship Uni- } \\
\text { versitas Muhammadiyah Yogyakarta }\end{array}$ & 8 June 2015 & Local & $\begin{array}{l}\text { Scolarship hold- } \\
\text { ers: } 4 \text { persons }\end{array}$ \\
\hline 13 & $\begin{array}{l}\text { Student Excange to Sias International } \\
\text { University, Tiongkok for one semester }\end{array}$ & $\begin{array}{l}\text { Odd Semester } \\
2015 / 2016\end{array}$ & $\begin{array}{l}\text { Interna- } \\
\text { tional }\end{array}$ & $\begin{array}{l}\text { Scholarship } \\
\text { holder: } 1 \text { person }\end{array}$ \\
\hline 14 & $\begin{array}{l}\text { SEKATEN International Culture Festival, } \\
10 \text { September } 2015 \text { (Savanna) }\end{array}$ & 15-Sep-2015 & Local & $\begin{array}{l}\text { English Musical } \\
\text { Drama “Malin } \\
\text { Kundang" }\end{array}$ \\
\hline 15 & $\begin{array}{l}\text { The 13th Asia TEFL International Con- } \\
\text { ference in China }\end{array}$ & $\begin{array}{l}\text { 6-8 November } \\
2015\end{array}$ & $\begin{array}{l}\text { Interna- } \\
\text { tional }\end{array}$ & $\begin{array}{l}\text { Paper presenters: } \\
2 \text { Presenters }\end{array}$ \\
\hline 16 & $\begin{array}{l}\text { The } 2015 \text { International Conference } \\
\text { "English Language Teaching Challenges } \\
\text { in Asia" }\end{array}$ & $\begin{array}{l}10 \text { November } \\
2015\end{array}$ & $\begin{array}{l}\text { Interna- } \\
\text { tional }\end{array}$ & $\begin{array}{l}\text { Paper presenter: } \\
1 \text { Presenter }\end{array}$ \\
\hline 17 & $\begin{array}{l}\text { The 6th International Language Learning } \\
\text { Conference, Penang Malaysia }\end{array}$ & $\begin{array}{l}2-4 \text { November } \\
2015\end{array}$ & $\begin{array}{l}\text { Interna- } \\
\text { tional }\end{array}$ & $\begin{array}{l}\text { Paper presenter: } \\
1 \text { Presenter }\end{array}$ \\
\hline 18 & JETA International Conference 2015 & 2015 & $\begin{array}{l}\text { Interna- } \\
\text { tional }\end{array}$ & $\begin{array}{l}\text { Paper presenters: } \\
2 \text { Presenters }\end{array}$ \\
\hline 19 & Students Creativity Grant 2014 & 2014 & National & $\begin{array}{l}\text { Grantees: } 5 \text { per- } \\
\text { sons }\end{array}$ \\
\hline 20 & $\begin{array}{l}\text { UMY Main Outstanding Students schol- } \\
\text { arship } 2014\end{array}$ & 2014 & Local & $\begin{array}{l}\text { Scholarship } \\
\text { holder: } 1 \text { person }\end{array}$ \\
\hline 21 & $\begin{array}{l}\text { UMY Outstanding Students Scholarship } \\
2014\end{array}$ & 2014 & Local & $\begin{array}{l}\text { Scholarship hold- } \\
\text { ers: } 3 \text { persons }\end{array}$ \\
\hline 22 & $\begin{array}{l}\text { The 11th Asia TEFL International Con- } \\
\text { ference in Philippines }\end{array}$ & October 2013 & $\begin{array}{l}\text { Interna- } \\
\text { tional }\end{array}$ & $\begin{array}{l}\text { Paper presenters: } \\
6 \text { presenters }\end{array}$ \\
\hline 23 & $\begin{array}{l}\text { Airlangga Cup Tapak Suci Indonesia } \\
\text { Open } 2013\end{array}$ & $\begin{array}{l}\text { 1-6 October } \\
2013\end{array}$ & National & $\begin{array}{l}\text { Runner Up } \\
\text { Group: } 2 \text { persons }\end{array}$ \\
\hline 24 & Exchange Program SUT - ASEAN 2013 & March 2013 & $\begin{array}{l}\text { Interna- } \\
\text { tional }\end{array}$ & Holder: 1 person \\
\hline 25 & UMY Students Creativity Grant 2013 & 2013 & National & $\begin{array}{l}\text { Holders: } 6 \text { per- } \\
\text { sons }\end{array}$ \\
\hline 26 & Telkomsel Mengajar Program 2013 & 2013 & National & $\begin{array}{l}\text { Awardee: } 1 \text { per- } \\
\text { son }\end{array}$ \\
\hline 27 & Bank Syariah Mandiri Scholarship 2013 & 2013 & National & $\begin{array}{l}\text { Scholarship re- } \\
\text { cievers: } 3 \text { persons }\end{array}$ \\
\hline 28 & Badan Pengelola Infaq Scholarship 2013 & 2013 & Local & $\begin{array}{l}\text { Scholarship re- } \\
\text { cievers: } 3 \text { persons }\end{array}$ \\
\hline
\end{tabular}


Leksika Vol.12 No.2 - Aug 2018: 72 - 81

\begin{tabular}{|c|c|c|c|c|}
\hline 29 & National Speech Contest 2013 & May 2013 & National & Host \\
\hline 30 & Saman Dance & $\begin{array}{l}\text { April-May } \\
2013\end{array}$ & Local & $\begin{array}{l}\text { Dancers: } 19 \text { per- } \\
\text { sons }\end{array}$ \\
\hline 31 & $\begin{array}{l}\text { Conference on Teaching English as a For- } \\
\text { eign Language, The 5th COTEFL }\end{array}$ & $\begin{array}{l}\text { 11-12 May } \\
2013\end{array}$ & $\begin{array}{l}\text { Interna- } \\
\text { tional }\end{array}$ & $\begin{array}{l}\text { Paper presenters: } \\
7 \text { presenters }\end{array}$ \\
\hline 32 & $\begin{array}{l}\text { BRI Stundent Enterpreunership and } \\
\text { Business Incubator (SEBI) Grant } 2013\end{array}$ & March 2013 & local & $\begin{array}{l}\text { Entrepreuneur- } \\
\text { ship Grant } \\
\text { Holder: } 5 \text { groups }\end{array}$ \\
\hline 33 & $\begin{array}{l}\text { International Conference on Education } \\
\text { and Language (ICEL) } 2013\end{array}$ & $\begin{array}{l}\text { 28-30 January } \\
2013\end{array}$ & $\begin{array}{l}\text { Interna- } \\
\text { tional }\end{array}$ & $\begin{array}{l}\text { Paper presenters: } \\
3 \text { presenters }\end{array}$ \\
\hline 34 & $\begin{array}{l}\text { Global Ugrad Fullbright Scholarship } \\
\text { USA } 2014\end{array}$ & $\begin{array}{l}\text { January - Mei } \\
2014\end{array}$ & $\begin{array}{l}\text { Interna- } \\
\text { tional }\end{array}$ & $\begin{array}{l}\text { Awardee: } 1 \text { per- } \\
\text { son }\end{array}$ \\
\hline 35 & $\begin{array}{l}\text { UMY Most Outstanding Students Schol- } \\
\text { arship } 2013\end{array}$ & 2013 & Local & $\begin{array}{l}\text { Awardee: } 1 \text { per- } \\
\text { son }\end{array}$ \\
\hline 36 & Academic Scholarship 2013 & 2013 & National & $\begin{array}{l}\text { Awardee: } 8 \text { per- } \\
\text { sons }\end{array}$ \\
\hline
\end{tabular}

\section{Conclusion}

From the implementation of the Competency Based Curriculum in the English Education Department, Faculty of Language Education, Universitas Muhammadiyah Yogyakarta, conclusion could be drawn as follows:

1. Competency Based Curriculum needs the implementation of student centred learning,

2. English Education Department Universitas Muhammadiyah Yogyakarta has applied Competency Based Curriculum and student centred learning with contextual learning process,

3. The learning process of the Competency Based Curriculum in the English Education Department Universitas Muhammadiyah Yogyakarta has created self directed learners or autonomous learners,

4. Thus, the implementation of the Competency Based Curriculum could accelerate the students' learning autonomy.

5. Learning autonomy drives the students achieve more than expected.

\section{References}

Benson, P. (1997). Autonomy and Independence in Language Learning. London: Longman.
Dickinson, L. (1987). Self-instruction in Language Learning. Cambridge: Cambridge University Press.

Hedge, T. (2000). Teaching and Learning in the Language Classroom. Oxford: Oxford University Press.

Holec, H. (1979). Aspects of Autonomy in Foreign Language Learning. Oxford: Parmagon. 